\title{
AN INDIVIDUAL IN SOCIETY: SELF-IDENTIFICATION PROCESSES IN MODERN CONCEPTS OF IDENTITY
}

\author{
JEDNOSTKA W SPOŁECZEŃSTWIE: PROCESY \\ SAMOIDENTYFIKACJI W ŚWIETLE WSPÓŁCZESNYCH \\ KONCEPCJI TOŻSAMOŚCI
}

\begin{abstract}
Paper contains analysis of several sociological, social-psychological and philosophical concepts of individual identity from the last quarter of $20^{\text {th }} \mathrm{c}$. and the turn of $21^{\text {st }} \mathrm{c}$. as a part of such theoretical perspectives as symbolic interactionism, sociology of action, theory of structuration as well as critical perspective of cultural postmodernism.

Selected publications in every perspective were carefully analysed with the relevant accent on the topics of identity and place of a human being in society.

The analysis and synthesis of the selected concepts and publications in general consists of the detailed presentation of self-concepts, individual identity in connection with the other important components of these concepts, including role identity theory, actionalist theory of a social subject, constructivist-structuralist theory of acting subject, free identity choice by consumer in Bauman's terms and individual identity project in the theory of structuration.

Every social scientist and researcher will gain a lot of inspiration as well as indispensable theoretical framework for better interpretation of empirical material in the field where one can rely on many years of fundamental research, elaborate consideration and intuitions by the outstanding commentators of social changes both on the national and global level.
\end{abstract}




\section{STRESZCZENIE}

W artykule zostały przedstawione wybrane socjologiczne, społeczno-psychologiczne i filozoficzne koncepcje tożsamości jednostki ludzkiej z ostatniego ćwierćwiecza XX w. oraz początku wieku XXI w ramach nurtów późnego interakcjonizmu symbolicznego, socjologii działania, teorii strukturyzacji oraz krytycznego nurtu postmodernizmu kulturowego.

Zostały przeanalizowane wybrane dzieła reprezentujące wspomniane perspektywy, czego dokonano z punktu widzenia tematyki tożsamości oraz miejsca jednostki we współczesnym społeczeństwie.

Analiza i synteza wytypowanych dzieł zawiera zwarte przedstawienie koncepcji Ja, tożsamości jednostki ludzkiej na tle innych istotnych elementów wspomnianych koncepcji, w tym teorii tożsamości roli, akcjonalistycznej koncepcji podmiotu społecznego, kontruktywistyczno-strukturalistycznej teorii podmiotu działającego, wolności wyboru tożsamości przez baumanowskiego konsumenta oraz indywidualnego projektu tożsamości w ramach teorii strukturyzacji.

Głębokie wieloletnie przemyślenia wybitnych obserwatorów zmian społecznych zarówno na poziomie społeczeństwa narodowego, jak i globalnego, ich niewątpliwie ciekawe intuicje oraz odkrycia fundamentalnych procesów mogą znacząco zainspirować oraz wyposażyć każdego badacza w niezbędny zestaw pojęć i pewne ramy dla interpretacji zdarzeń empirycznych.

KEYWORDS: self, role identity, symbolic interactionism, habitus, consumer, structuration, routine

SŁOWA KLUCzowe: jaźń, tożsamość roli, interakcjonizm symboliczny, habitus, konsument, strukturyzacja, rutyna

"The social identity lies in difference,
and difference is asserted against what is closest,
which represents the greatest threat."

Pierre Bourdieu

Distinction. A Social Critique of the Judgement of Taste

(Bourdieu, 2010, s. 481)

\section{WPROWADZENIE}

Początek XXI w. przyprawił o zawrót głowy większość analityków i teoretyków zmiany społecznej na różnych poziomach złożoności. Jednostkę ludzką również dosięgły prowokujące myśli i pytania. Kim jesteśmy, kiedy jesteśmy tym, kim jesteśmy? - zapytał Sławomir J. Magala w swoim eseju o tożsamościach na wybór, identyfikacji jako subiektywnym utożsamianiu z określoną 
grupą oraz identyzacji jako wyobrażeniu tego, czym jest jednostka sama dla siebie ze względu na swoją biografię i wartości (Bokszański, 1989, s. 17). „Tożsamości jednostkowe i społeczne, w których kiedyś były trwale osadzone decyzje, intencje i wierzenia, zostały w ciągu wieku XX podważone”. (Magala, 2002). Pojęcie tożsamości jest wpisane do rejestru podstawowych kategorii socjologicznych, tworzącego wielość możliwości analitycznych bez konieczności odniesienia się do złożoności społeczeństwa, miejsca aktora społecznego czy potrzeby ciągłego podejmowania wyborów przez samoświadomą jednostkę w odniesieniu do tworzenia i odtwarzania swojej tożsamości jako układu autodefinicji (Bokszański, 1989, s. 5, 14; Giddens, 2004, s. 52-53). Wielu z nas przeważnie uważa tożsamość jako coś oczywistego. My wiemy, kim jesteśmy, mamy dość dobrą roboczą definicję tego, kim są w naszym życiu Inni, którzy podobnie odnoszą się do nas. Ale wcześniej czy później, jak stwierdził Richard Jenkins, może nadejść chwila, że tożsamość stanie się bardzo ważną kwestią (Jenkins, 2005). Identyfikacja nas lub Innych jest procesem, w szczególności, jeżeli chcielibyśmy mieć określony wpływ na to, w jaki sposób ludzie nas postrzegają, i ma to duże znaczenie dla nas, naszych grup społecznych oraz ogólnie kontekstu, w którym przebywamy, na poziomie wspólnoty kulturowej, obywatelskiej, społeczeństwa w ramach państwa czy narodu (Sitek, 2015, s. 117).

Tożsamość i proces identyfikacji oddziałuje na rzeczywiste doświadczenie ludzkie jako jedna z najbardziej prozaicznych i jednocześnie zadziwiających rzeczy. Z jakiejkolwiek strony nie popatrzylibyśmy na to zjawisko, okazuje się ono ważne zarówno w życiu codziennym, jak i w socjologii. W tym opracowaniu przedstawiłam kilka w moim odczuciu najważniejszych perspektyw teoretycznych, które odnoszą się w ten lub inny sposób do tożsamości, często w ścisłym związku ze zmianami społecznymi, które zachodzą od kilku dziesięcioleci z różnym natężeniem i prędkością praktycznie we wszystkich krajach na świecie. Odwołuję się do wcześniejszego własnego opracowania klasycznych teorii tożsamości głównie z zakresu psychologii społecznej oraz interakcjonizmu symbolicznego, a także wcześniejszych gruntownych analiz socjologów tożsamości oraz historyków myśli socjologicznej z kręgu polskiego i anglosaskiego dyskursu naukowego (Novikova, 2013; Bendle, 2002; Bokszański, 1989; Bokszański, 2005; Burke, Stets, 2009; Elliott, 2011; Hałas, 2005; Jawłowska, 2001; Jenkins, 2005; Kaufmann, 2004; Misztal, 2000; Turner, 2004). 


\section{TEORIA TOŻSAMOŚCI ROLI}

Wśród współczesnych kontynuatorów tradycji interakcjonistycznej, rozwijających m.in. zagadnienia jaźni i wielości tożsamości, z których jest ona konstruowana, warto wymienić Anselma Straussa, Sheldona Strykera, Petera Burke, Richarda Serpe oraz wielu innych młodszych reprezentantów tego nurtu (por. Stryker, 1981). Z grona przedstawicieli amerykańskiego interakcjonizmu symbolicznego $\mathrm{w}$ lat $60 . \mathrm{XX} \mathrm{w}$. moją uwagę przyciągnęli George J. McCall i Jerry L. Simmons (Turner, 2004, s. 439-444). Sformułowali i dopracowali oni specyficzną teorię tożsamości, w której rola i improwizacja w ramach roli zajmują szczególne miejsce w życiu jednostki, jej dążeniu do realizacji licznych celów życiowych, gdzie struktura społeczna i kultura w mniejszym stopniu ograniczają dynamikę tożsamości, a jednostka ma większy zakres wolności w jej konstruowaniu.

Proces identyfikacji jest nieodłączną częścią interakcji i polega na tym, że jednostka dzięki jaźni refleksyjnej jest zdolna do analizy siebie jako przedmiotu, kategoryzacji, klasyfikacji oraz „nazywania”. W przebiegu tego procesu identyfikacji kształtuje się tożsamość jednostki. Klasyfikacja i nadawanie nazw, zakorzenione w pewnej kulturze, odbywają się za pomocą odpowiednich symboli, określających pewne relatywnie stabilne pozycje i role jako komponenty struktury społecznej. Nazywać kogoś w jakiś sposób oznacza uznawać kogoś za zajmującego pewną pozycję lub wykonującego rolę (Burke, Stets, 2000, s. 225). Jednostka nadaje nazwy, identyfikuje wszystkich i wszystko, co ma większe lub mniejsze znaczenie dla realizacji jej celów i planów.

Tożsamość roli (ang. role identity) to postać i rola, jaką jednostka wybiera dla siebie jako osoby, która zajmuje pewną pozycję społeczną, czasami określaną jako status społeczny czy nawet typ społeczny (McCall, Simmons, 1978, s. 64-65). McCall i Simmons połączyli wpływ struktury społecznej, na którą składają się pozycje zajmowane przez jednostki z konstruktywistycznym podejściem do tożsamości jako czegoś wyobrażanego, jako specyficznego spojrzenia na siebie. Negocjacja roli stała się swego rodzaju kompromisem między idealną, "preferowaną" tożsamością jednostki a oczekiwaniami innych i potrzebą stabilnych zobowiązań jednostek w codziennych interakcjach. Utożsamianie się z czymś oznacza również odrzucenie utożsamiania się, czyli dezidentyfikację (ang. disidentification) z innymi obiektami społecznymi, 
które odróżniają się od tych pierwszych. W swoich późniejszych analizach McCall zaproponował wyróżnienie bliźniaczych procesów identyfikacji vs dezidentyfikacji jako pozytywnego i negatywnego bieguna tożsamości, które określił jako „Me” i „Not-Me”, czyli „Ja” i „nie-Ja”, jako odpowiedzi na pytania „kim jestem” oraz „kim nie jestem” (McCall, 2011, s. 12).

Tożsamość roli zawiera tzw. „luźne, ale spójne wskazówki, stabilizujące ludzkie działania” (Misztal, 2000, s. 146). W konstruowaniu tożsamości znaczące pozostaje spojrzenie innych na jednostkę, bowiem ludzkim zachowaniem kieruje „uprawomocnienie własnej tożsamości w oczach innych” (Turner, 2004, s. 442-443). Zgodność zachowań ludzkich z pewnymi wymaganiami przypisanymi do roli stanowi ważną część potwierdzania tożsamości roli. Odgrywanie ról w różnorodnych relacjach i powiązaniach opiera się na wzajemności i wymianie. W tym przejawiają się elementy teorii wymiany z odpowiednią dynamiką oraz szeregiem nagród w interakcjach. Jednostka rozpatruje siebie nie jako podobną do innych, lecz różniącą się pod wieloma względami, zwłaszcza interesów, które można pogodzić tylko przy pomocy negocjacji roli. Wyniki tej negocjacji zależą również od indywidualnej hierarchii ważności tożsamości, czyli wzajemnego dopasowania różnorodnych elementów tożsamości. Hierarchia ta wyznacza, w które tożsamości jednostka jest bardziej zaangażowana, prezentację którego z elementów tożsamości przeprowadzi w tej lub innej interakcji, do potwierdzenia którego będzie dążyć najbardziej (Burke, 2009, s. 30).

Jednostka powinna zachowywać się konsekwentnie, zgodnie ze skonstruowaną jaźnią, definicją siebie, czyli nadal „być sobą” (Blumstein, 1975, s. 477). Żeby podtrzymać swoją tożsamość, powinna ona uzyskać tzw. poparcie dla roli (ang. role support), czyli przyznane jednostce przez publiczność prawo do zajmowania danej pozycji, akceptację jej zachowania, emocji, stylu, zwyczajów (McCall, Simmons, 1978, s. 71-72). Sama dla siebie jednostka występuje jednak jako najważniejsza publiczność dla wykonania roli, oceniając siebie pod względem tej preferowanej wizji tożsamości roli.

Poszukiwanie poparcia, uzasadnienie twierdzeń na temat swej tożsamości, potwierdzenie „wyidealizowanej koncepcji siebie” jest powszechną formą prezentacji siebie. Najpotężniejsze poparcie dla roli nadchodzi jednak z kilku stron z zewnątrz, wbrew możliwej niezgodności i rozłączności 
między tym poparciem a tożsamością roli, która może zostać błędnie zinterpretowana, później zaś negocjowana i poparta przed publicznością przy pomocy licznych mechanizmów podtrzymywania poparcia dla roli. Odbywa się to np. przez selektywne postrzeganie wskazówek, ich wybiórczą interpretację, poszukiwanie bardziej przyjaznych sytuacji alternatywnych, zachowanie kredytu emocjonalnego, uzyskanego w najbardziej pozytywnych interakcjach albo konstruowanie całkowicie nowej tożsamości roli, mającej uzyskać więcej poparcia oraz szereg innych działań (McCall, Simmons, 1978, s. 141, 247; Turner, 2004, s. 441). Potrzeba poparcia dla roli, hierarchia ważności, negocjacje oraz wpływ czynników, związanych z konkretną interakcją kształtują tzw. „ja”, usytuowane, płynne i zmienne, w największym stopniu stosujące się do sytuacji bieżącej oraz w dużej mierze wyznaczające ten lub inny wybór jednostki. Na najwyższej pozycji w hierarchii znajduje się jednak „ja” idealne, bardziej trwałe od „ja” usytuowanego, wytwarzające to ostatnie, wyznaczające, jaka tożsamość roli będzie przywołana w określonej sytuacji (McCall, Simmons, 1978, s. 86; Burke, Stets, 2009, s. 41). Te dwa rodzaje tożsamości w hierarchii zróżnicowanych tożsamości określane są jako tożsamości uwydatnione.

W swej teorii tożsamości roli McCall i Simmons dążyli do połączenia znaczenia koncepcji siebie jednostki oraz wpływu kontekstu społecznego i kulturowego w próbie zrozumienia mechanizmów kształtowania tożsamości jednostki i jej zachowań. Lecz jako przedstawiciele nurtu interakcjonistycznego zasadniczy wpływ przypisywali osobie, jej jaźni i działaniom, czyli wolności w konstruowaniu wielości własnych tożsamości, wyborze tej lub innej opcji kulturowej w przebiegu interakcji, w przyjęciu tej lub innej roli lub pozycji.

\section{Aktor spoenczny Alaina Touraine'a}

Kolejną perspektywą, którą przedstawię tutaj, będzie koncepcja należąca nurtu, określanego również jako socjologia działania, który w analizie działań jednostkowych stawia równie istotny akcent na inne jednostki oraz społeczeństwo jako całość. Poglądy Alaina Touraine’a - francuskiego teoretyka ruchów społecznych, a w ostatnim okresie również tożsamości aktora społecznego, którą rozpatruje on w ścisłej więzi z zagadnieniami ruchu społecznego, składają się m.in. na perspektywę socjologii akcjonalistycznej. Zgodnie z jej głów- 
ną przesłanką społeczeństwo współczesne jest efektem czy produktem działań własnych, nie zależąc już od „wyższych” czynników pozaspołecznych lub „metaspołecznych gwarantów porządku społecznego”, takich jak religia, ekonomia, rasa, historia, walka klas (Bokszański, 1989, s. 217-218). Zdaniem Touraine’a obecnie pojawia się pytanie o źródła sensu i racje istnienia struktur społecznych, o znaczenie samoświadomości społeczeństw oraz tożsamości ich członków, bowiem „każdy sposób myślenia, którego punktem wyjścia jest jednostka, nawet jeśli dostrzega w niej aktora społecznego lub osobowy podmiot, zderza się z zastrzeżeniem: ludzie nie żyją w samotności, ich warunki życia zależą od warunków życia innych". Touraine mówi już nie o indywidualizmie, lecz o egoizmie, podsycanym ponad miarę dążeniu do osobistych korzyści i istotnym osłabieniu zbiorowych solidarności (Touraine, 2011, s. 213).

W socjologii akcjonalistycznej społeczeństwo nie jest ani maszyną, ani organizacją, występuje raczej jako działanie, jako „całokształt zhierarchizowanych systemów działania, czyli stosunków społecznych między aktorami, które podzielają pewne orientacje kulturowe" (Bokszański, 1989, s. 219). Ruchy społeczne są działaniem zbiorowym, ujawniającym problemy i starcia często sprzecznych orientacji kulturowych i różnorodnych ideologii w społeczeństwie.

Ważnym pojęciem w koncepcji Touraine’a są relacje społeczne, ujęte w sposób odgraniczający je od pojęcia interakcji jako bezwzględnie wymagającego wspólnych wartości, norm albo nawet dominującej świadomości zbiorowej. Największą krytykę wywołuje jednak pojęcie roli społecznej, przypisanej aktorowi społecznemu. Pojęcie to w myśli Touraine’a koniecznie trzeba zastąpić koncepcją tożsamości aktora społecznego. Powszechnie podzielane wartości i wzory zachowań, uzgodnione przez partnerów interakcji lub narzucone przez kontrolę społeczną oczekiwania zakładają konsensualną wizję społeczeństwa, która nie znajduje potwierdzenia we współczesnym stadium dynamicznych zmian społecznych i nawet strukturalnych właściwości współczesnego społeczeństwa post-industrialnego (Bokszański, 2005, s. 24-25). Jak to trafnie ujął Misztal, „globalizacja zmieniła naturę tożsamości, obnażyła ją i wyłuskała z kontekstu roli społecznej, uwolniła od roli determinującego wpływu i odarła z pewności, jaka się wiązała z konstruowaniem tożsamości w warunkach społeczeństwa przemysłowego" (Misztal, 2000, s. 144-145). Touraine natomiast zaznacza, że tak częsty współcześnie apel o tożsamość 
oznacza przede wszystkim odrzucenie roli, czyli społecznego określenia roli, jako czegoś, co aktor społeczny musi odgrywać (Touraine, 1988, s. 75).

Ewentualny „konsensus społeczny” nie uwzględnia również wspomnianych możliwych problemów i sprzeczek między aktorami społecznymi, dotyczących odmiennego pojmowania wspólnej przestrzeni społecznej i odpowiedniego konstruowania rozbieżnych modeli funkcjonowania społeczeństwa. Te modele wyłaniają się z działalności ruchów społecznych oraz aktorów społecznych, których tożsamość jest w nie zaangażowana. W taki sposób pojęcie tożsamości pozwala pokazać nieewolucjonistyczną dynamikę relacji społecznych i społeczeństwa, której owocem i wskaźnikiem są „przejawy kontestacji, odchodzenia od oficjalnych ideologii, kwestionowania przypisanych powinności, propagowania nowych stylów życia” (Bokszański, 1999, s. 60). Jednak przedmiotem socjologii nie są właściwie aktorzy, lecz ich stosunki i praktyki, których oni sami mogą nie rozumieć, aktor jest więc czymś wtórnym wobec relacji społecznych (Bokszański, 1989, s. 219). Nie neguje to wprawdzie znaczenia jego istnienia, tożsamości, wkładu w całokształt relacji, jego podmiotowości i aktywności. Jednostka bowiem odkrywa obecność „ja” w sobie w tym samym czasie, kiedy odkrywa ochotę bycia podmiotem (aktorem) (Touraine, 1992, s. 243).

Tożsamość aktora społecznego w ujęciu socjologii akcjonalistycznej to jego „autodefinicja wyposażona w potencję generowania określonego zbioru działań”, co wskazuje na podmiotową perspektywę koncepcji tożsamości (Bokszański, 2005, s. 29; Touraine, 2011, s. 155-188). Aktywność i autonomiczność aktora społecznego w tworzeniu jego autodefinicji zależy jednak od pewnych warunków, np. od tego, czy porządek społeczny występuje jako „dzieło ludzi, jako projekcja stosunków społecznych”, oraz czy działają ruchy społeczne jako społecznie dostrzegalne wyrazy konfliktu w społeczeństwie (Bokszański, 1989, s. 225; Touraine, 2011, s. 189-212). Zbudowana na podstawie uczestnictwa w ruchu społecznym tożsamość przekracza własne granice i możliwości, wykracza poza przypisane aktorowi miejsce w strukturze relacji społecznych. Dzięki niej ruch społeczny zdolny jest do osiągnięcia szerszych, ważniejszych celów, może nawet zmienić dominujące formy polityczne i instytucjonalne (Bokszański, 1989, s. 226-228).

Z drugiej strony Touraine wyodrębnia tożsamość iluzoryczną, skonstruowaną próbnie przed zaangażowaniem w ruch, opartą najczęściej na statusie 
instytucjonalnym lub organizacyjnym, mniej wartościową z punktu widzenia podmiotu autonomicznego. Całościowa, „prawdziwa” tożsamość społeczna również nie sprowadza się do prostej koncepcji siebie, która właściwa jest wszystkim ludziom, ale pozbawiona jest tego komponentu autonomiczności i aktywności podmiotu społecznego, określającego prawdziwą sytuację danego aktora w globalnym układzie relacji.

Mówi Touraine też o tzw. tożsamościach kulturowych, ukształtowanych w warunkach panowania „metaspołecznego gwaranta porządku społecznego", polegających na przynależności do wspólnoty wartości, społecznych lub naturalnych atrybutów (Bokszański, 1989, s. 229). Do tych tożsamości apelują bowiem ruchy społeczne na pierwszym etapie swego formowania, wzywając do podjęcia fundamentalnych kwestii życia, wolności, twórczości w przeciwieństwie do sztywniej wyznaczonych roli społecznych (Touraine, 1988, s. 75; 2011, s. 196). Tożsamości tego rodzaju i idee, do których nawiązują ruchy społeczne, charakteryzują się jednak niejasnością, chociaż i coraz większą popularnością wśród źródeł znaczeń istotnych dla ruchów w ich kampanii przeciwko dominacjom. Coraz bardziej urozmaicona dominacja społeczna sięga najbardziej oddalonych obszarów społeczeństwa, pozostawiając dla sprzeciwu i obrony tylko te najmniej społeczne, usytuowane najbliżej natury (w sferze działań zbiorowych) oraz ciała (w sferze relacji interpersonalnych) i podświadomego (w sferze osobowej) (Touraine, 1988, s. 78). Touraine przytacza inne poglądy na „obronne zachowanie” tożsamości, która przekształca się w „urywany ciąg identyfikacji z modelami, wytworzonymi przez kulturę masową" (Touraine, 1988, s. 80).

Apel do tożsamości i jej obrony nadaje rzeczywistą potęgę działaniom społecznym, „ponieważ obrona stanowi połowę działania” (Touraine, 1988, s. 78). Jednak, aby powołać prawdziwy ruch społeczny, zdaniem Touraine’a, ten opór musi nawiązać do tzw. ruchu „kontrofensywnego”, w większym stopniu zdolnego do efektywnego działania zbiorowego, do walki o prawa, możliwość samodzielnego określania własnego życia społecznego i osobistego, a nawet do walki o władzę. Jeszcze bardziej aktualne i aktywne wg Touraine’a są ruchy ofensywne, które występują przeciwko dominacji, która niszczy nie tyle tożsamość (wspomnianą kulturową), ile zdolność zbiorowości i jednostek do autonomicznej interwencji i działania w społeczeństwie. 
W wyniku rozumowań wiążących ruchy oraz tożsamości powstaje definicja tożsamości, najbardziej odpowiadająca współczesnemu etapowi rozwoju społecznego. Tożsamość nie polega już na odwoływaniu się do sposobu bycia, do przyrody. Wyraża się w pragnieniu możliwości działania i zmiany. Definiowana jest w terminach wyboru, uświadomienia i kontroli, czyli działania, a nie sensu, substancji lub tradycji (Touraine, 1988, s. 81). Jest świadomością możliwości dążeń i zmian, które aktor społeczny dzięki swojemu zaangażowaniu w ruchu społecznym jest zdolny przeprowadzić w globalnym układzie relacji społecznych.

\section{Habitus Pierre'a Bourdieu}

Wśród nowoczesnych teorii socjologicznych wypowiadających się na temat jednostki i jej powiązań ze społeczeństwem wyróżnia się „konstruktywistyczno-strukturalistyczna” wersja Bourdieu z jego koncepcją habitusu i szeregiem innych specyficznych pojęć. Pojęcie habitusu nie zastępuje pojęć jaźni, „Ja” lub tożsamości jednostki, pomaga zaś uwzględnić różne wymiary zjawisk, nie sprowadzając procesów społecznych do nadmiernej obiektywizacji lub subiektywizacji. Nauka społeczna nie musi bowiem wybierać między tymi dwoma biegunami, gdyż to, co tworzy rzeczywistość społeczną - tyleż habitus, co i struktura oraz ich wzajemne przenikanie się w postaci historii - tkwi w relacjach (Bourdieu, Wacquant, 2001, s. 20). Z innej strony, rzeczywistość społeczna istnieje jak gdyby dwukrotnie, „w rzeczach i w mózgach, w polach i habitusach, na zewnątrz i wewnątrz podmiotów działających" (Bourdieu, Wacquant, 2001, s. 115).

Koncepcja habitusu nie była jednak wymyślona w całości przez Bourdieu, jest związana $\mathrm{z}$ takimi pojęciami jak przyzwyczajenia i nawyki (fr. habitude), a jej pojawienia się komentatorzy dorobku francuskiego socjologa dopatrują się nawet u Arystotelesa (Matuchniak-Krasuska, 2010, s. 27). Jean-Claude Kaufmann nazywa właśnie to pojęcie wielkim osiągnięciem Bourdieu, który pozostawił w ramach mowy potocznej przyzwyczajenia, a użył łaciny w próbie pewnego startu od zera dla celów ofiarowania „pięknego, wielkiego, bardzo czystego i bardzo określonego pojęcia”, któremu nie poświęcił w całości żadnej pracy, ale w każdej pracy go używał (Kaufmann, 2004, s. 123-124). 
Niektórzy socjolodzy upatrują bliskość teorii Bourdieu z ich własnym rozumowaniem na temat tożsamości i tożsamości społecznej. Jak zauważa Richard Jenkins, mimo że koncept habitusu może wydawać się problematyczny w niektórych aspektach, jest bliski takiej wizji tożsamości, w której jest ona jednocześnie „zbiorowa i osobowa, i na pewno wcielona”. Habitus nie działa ani świadomie, ani nieświadomie, ani celowo, ani automatycznie, jednak ułatwia i popiera improwizację w interakcjach i procesie "prezentacji siebie” (Jenkins, 2005, s. 20).

Z drugiej strony, pojęcie tożsamości lub też tożsamości społecznej pojawia się w wieloaspektowych koncepcjach Bourdieu poza habitusem, lecz wiąże się najczęściej z zagadnieniami subiektywnych wyobrażeń na temat własnej niezmienności i nierozerwalności jaźni, własnego „Ja”. „Iluzja biograficzna” - tak Bourdieu określa ten proces, w którym duże znaczenie ma np. czynność mianowania, nadawania imienia własnego, które „instytucjonalizuje” tożsamość społeczną jako stałą i trwałą. Ta ostatnia z kolei gwarantuje zachowanie tożsamości jednostki biologicznej na wszystkich możliwych polach, na których ona działa jako podmiot (Bourdieu, 1994, s. 85). Istotą imienia własnego jest więc widzialne zaświadczenie identyczności jego nosiciela w czasie i przestrzeni oraz podstawa jedności kolejnych takich zaświadczeń. Podobną rolę w zaświadczaniu tożsamości społecznej odgrywają również dowody tożsamości, karta stanu cywilnego, curriculum vitae, oficjalna biografia i inne aspekty „zewnętrznej strony społecznej” (fr. surface sociale) i rygorystycznego opisu osobowości jednostki (Bourdieu, 1994, s. 86-89). Osobowość Bourdieu definiuje jako jednostkę biologiczną, „instytucjonalizowaną społecznie” przez mianowanie i posiadanie pewnych oznak, właściwości i praw zapewnionych przez „zewnętrzną stronę społeczną", innymi słowy, zdolność jednostki, by istnieć jako podmiot na zróżnicowanych polach (Bourdieu, 1994, s. 89).

Pole, jak i habitus w koncepcji Bourdieu to splot relacji obiektywnych, usytułowanych między pozycjami znajdującymi się w pewnych formach władzy lub kapitału. Historyczne i obiektywne relacje jako habitus występują w jednostce $\mathrm{w}$ postaci trwałych i dających się przenosić myślowych i cielesnych wzorów percepcji, ocen i działań, pewnego mechanizmu modelującego. Przy tym habitus nie jest ani wyłącznie indywidualny, ani determinujący 
zachowania. Jest „społecznie tworzoną podstawą postrzegania i oceny”, zasadą generującą strategię, pozwalającą radzić sobie w sposób dość spójny i systematyczny z wyzwaniami płynącymi z konkretnego pola w bardzo różnych sytuacjach (Bourdieu, Wacquant, 2001, s. 20-24). Ta różnorodność i nieokreśloność jest związana z faktyczną nieuchwytnością habitusu jako „niewidocznego miejsca”, swego rodzaju „twórczą zdolnością operacyjną”, która sprzyja tzw. komutatywności tego pojęcia, braku sprecyzowania oraz ruchomości. Bourdieu używa różnych pojęć, jak: „kapitał”, „pole”, „ciało”, a nawet „struktury obiektywne” czy „instytucje”, ale „habitus” przechodzi przez te różne elementy społeczeństwa, niebędąc sprowadzany do żadnego z nich (Kaufmann, 2004, s. 138-139).

Relacja pomiędzy aktorem a strukturą jest zastępowana relacją pomiędzy habitusem a polem (Bourdieu, Wacquant, 2001, s. 125). Przy tym oba mogą istnieć tylko w relacji z drugim. Dla każdego pola charakterystyczne są pewne wymogi. Przejawiają się one w habitusach, mniej lub bardziej spójnych, w zależności od relacji różnych pól. To nie aktor czy jednostka jest czy powinna być wyłącznym przedmiotem rozważań nauk społecznych, tylko pole, które niewątpliwie również nie istnieje poza jednostkami. Nie można go skonstruować w oderwaniu od jednostek ,jako nośników informacji” (Bourdieu, Wacquant, 2001, s. 90). Ocenia się przede wszystkim efektywność badań społecznych, w których jednostka jest istotna tylko jako aktywny „podmiot działający”, a nie zwykłe indywiduum biologiczne, „organizm zsocjalizowany", aktor czy podmiot. Owe działanie przejawia się również w kształtowaniu, konstrukcji poznawczej lub świadomościowej pola „jako świata znaczącego, obdarzonego sensem i wartością", w który podmioty inwestują swoją energię (Bourdieu, Wacquant, 2001, s. 114, Matuchniak-Krasuska, 2010, s. 30-31).

Uwaga skierowana na badanie pola, zdaniem Bourdieu, pozwala nawet lepiej zrozumieć istotę wyjątkowości każdej osoby, wynikającej z zajmowanej przez nią na danym polu pozycji na mocy posiadanego „kapitału” różnego rozmiaru i struktury, takiego „specyficznego kapitału skutecznych właściwości” (Bourdieu, Wacquant, 2001, s. 91-92; Matuchniak-Krasuska, 2010, s. 35-39). Pole jest niezwykle ważnym przedmiotem badań, ale warto pamiętać, że jako teren gry „istnieje o tyle tylko, o ile wchodzą tu gracze wierzący w korzyści, które gra im przyniesie i aktywnie do nich dążący” (Bourdieu, 
Wacquant, 2001, s. 23; Matuchniak-Krasuska, 2010, s. 40). Ci gracze, czyli podmioty działające poza chęcią wejścia do gry, powinni mieć również określone do tego dyspozycje i umiejętności oraz zdolności do improwizacji. Wciągnięcie w grę, interes podmiotów, „milczące uznanie wartości stawek zaangażowanych w grę i praktyczne opanowanie jej reguł” określa Bourdieu jako tzw. illusio, specyficzną formę interesu, charakterystyczną dla każdego pola z osobna (Bourdieu, Wacquant, 2001, s. 101-102).

Podmiot działający dla Bourdieu nie jest podmiotem racjonalnym. Jego działanie opiera się na zmyśle praktycznym i społecznie wytworzonym zmyśle gry. Zgodnie z tym, jak przeformułowuje tok rozumowania Bourdieu Loïc J.D. Wacquant, „zmysł praktyczny to taki zmysł społeczny, który kieruje nami nawet zanim „poukładamy” sobie przedmioty jako takie” (Bourdieu, Wacquant, 2001, s. 24). Działanie zaś nie jest mechaniczną, bezpodmiotową reakcją, nie jest to też rozmyślne spełnienie świadomego zamiaru, swobodna projekcja świadomości, stawiającej sobie cele i maksymalizującej korzyści za pomocą racjonalnego rachunku (Bourdieu, Wacquant, 2001, s. 107). U podstaw praktyk podmiotu działającego leży habitus jako zdolność tworzenia, generowania. Nie jest to zwyczaj czy nawyk, lecz aktywny stosunek do świata, chociaż również nie jest to „działanie kierowane świadomą wizją wprost sformułowanych celów” (Bourdieu, Wacquant, 2001, s. 112). Bourdieu również używa pojęcia „agent społeczny”, oznaczającego podmiot z pewnym pierwiastkiem społecznym, czyli pierwiastkiem dyspozycji ponadindywidualnej w myślach, uczuciach i działaniach, nawet w najbardziej subiektywnych aktach jednostki ludzkiej. Jest to pojęcie dość bliskie pojęciu „aktor społeczny”, używanemu w ramach nurtu interakcjonizmu symbolicznego (Matuchniak-Krasuska, 2010, s. 25).

Wśród krytyków Bourdieu można spotkać poglądy, zgodnie z którymi habitus przedstawia się jako „nieświadoma struktura motywacyjna”, konfigurowana przez zewnętrzne i sztywne struktury (zwłaszcza ekonomiczne), kształtująca następnie wszystkie doświadczenia i percepcje, nie pozwalając na żadne zmiany w tożsamości i wartościach, transmitowanych przez socjalizację, na żadną autonomię, przypadek lub nonkonformizm (Misztal, 2000, s. 149). Warto wspomnieć przy tym koncepcję Bourdieu aktywnego podmiotu działającego, który posiada otwarty system dyspozycji, „bez przerwy 
konfrontowanego z nowymi doświadczeniami, ciągle poddawanego ich wpływom" (Bourdieu, Wacquant, 2001, s. 122). Chociaż z innej strony, możemy również obserwować stałość dyspozycji, upodobań i preferencji w habitusie, uformowanym $\mathrm{w}$ warunkach identycznych $\mathrm{z}$ aktualnym, niewymagających „świadomych i intencjonalnych poszukiwań sposobu dostosowania” (Bourdieu, Wacquant, 2001, s. 117-122).

Habitus jest „uspołecznioną subiektywnością", bowiem to, co jednostkowe, subiektywne i osobiste jest jednocześnie społeczne i zbiorowe. Wacquant upatruje w tym swego rodzaju przesłanie moralne w teorii Bourdieu. Im bardziej jednostka działa na podstawie tylko subiektywności, tym bardziej prawdopodobne, iż pozostanie pozornym podmiotem działań, gdyż rzeczywistym sprawcą będzie struktura i „uwewnętrzniona obiektywność". Z innej strony, im lepiej ten pierwiastek społeczny będzie uświadomiony, tym więcej jednostka jako „podmiot rozumny” nabierze umiejętności analizy kategorii swego myślenia i działania, głębokiej refleksji i krytyki, dzięki którym potrafi kontrolować „zewnętrzność” (Bourdieu, Wacquant, 2001, s. 37-38).

Pojęcie habitusu pozwala spojrzeć na zjawisko tożsamości z uwzględnieniem zarówno obiektywnego, jak i subiektywnego wymiaru jednostki, jej życia i świata. Habitus jest swego rodzaju częścią tożsamości, zapewne najbardziej stałą, zorientowaną na utrwalenie, chociaż również otwartą na przekształcenia, opartą na przeszłych i aktualnych praktykach jednostki.

\section{ZYGMUNTA BAUMANA TYPY TOŻSAMOŚCI PONOWOCZESNEJ}

W ostatnim dziesięcioleciu XX w. najwięcej uwagi pojęcie tożsamości zyskało w związku z radykalnymi zmianami rzeczywistości społecznej, ukształtowaniem takiego typu społeczeństwa, który m.in. Zygmunt Bauman nazywa społeczeństwem ponowoczesnym. Pewne cechy charakterystyczne tego etapu historii wpływają na przebieg konstruowania tożsamości i jej formy, przenosząc dyskusję teoretyczną z zagadnień istoty zjawiska tożsamości na kwestie jej specyfiki w okresie ponowoczesności.

Proces kształtowania tożsamości doskonale odzwierciedla zmiany w sposobie pojmowania czasu, trwałości i ciągłości, bowiem długa, cierpliwa, czasochłonna praca przy formowaniu tożsamości, konsekwentność i stałość 
przestają mieć jakiekolwiek znaczenie. Jak zauważa Bauman, jeśli w nowoczesności problematyczna była kwestia, jak skonstruować tożsamość oraz utrzymać ją w stabilności, trwałości, stałości, współcześnie najważniejsze jest uniknięcie utrwalenia i zobowiązań, zachowanie otwartości wszystkich możliwych opcji (Bauman, 1996, s. 18-19).

Tożsamość w ujęciu Baumana nawiązuje do kilku wymiarów. Jest pewnego rodzaju odpowiedzią na pytanie o przynależność jednostki, czyli o to, „gdzie siebie sytuuje w różnorodności stylów i wzorców zachowań, oraz jak się upewnić, że ludzie dookoła przyjmą to usytuowanie jako słuszne i właściwe, żeby obie strony były pewne tego, jak postępować w obecności drugiej”. Jak to obrazowo ujmuje Bauman, tożsamością nazywa się ucieczkę od niepewności, ma ona charakter czasownika, nie zaś rzeczownika, jest przypuszczeniem, projektem, mających się zrealizować dopiero w przyszłości (Bauman, 1996, s. 19). Tożsamość jest pośrednim stwierdzeniem niedostateczności i niepełności tego, „czym jesteśmy” (Bauman, 1995, s. 82). Najważniejszą rolę w tym Bauman przypisuje jednostce i jej wolności wyboru, bowiem ucieczka i projekt są dziełem człowieka już w nowoczesności. W ponowoczesności ta niezależność doprowadza jednak do wzrostu znaczenia ekspertów i kultury, kształtowanej przez coachów, doradców, trenerów, instruktorów w zakresie tego, jak najlepiej tożsamość może być uzyskana i utrzymana (por. Novikova, 2016). Z tym się wiąże również szeroko rozpowszechniony współcześnie dyskurs terapeutyczny (Jacyno, 2007).

Przywołane wyżej charakterystyki „cierpliwości” składają się na typ pielgrzyma, który jest figurą nowoczesności, jedną z kilku metafor określających typy tożsamości i późniejsze zmiany w nich. Pielgrzym zawsze jest nie tam, gdzie marzy. W jego życiu najważniejszy jest punkt przeznaczenia oraz wiodące tam drogi, a nie domy, dające czasowy odpoczynek. Ponadto bez określonych cech świat się wydaje pustynią. Przywrócenie światu określoności i znaczenia odbywa się poprzez konstruowanie tożsamości przez pielgrzyma, które pozostaje nigdy niekończącym się działaniem, dzięki któremu świat nadal istnieje (Bauman, 1996, s. 22). Odległość od celu ostatecznego i opóźnienie, pewnego rodzaju niezadowolenie było sensem życia pielgrzyma, życia ukierunkowanego, ciągłego i niepoddającego się zmianom.

Współczesne zmiany, zdaniem Baumana, przejawiły się w problematyzowaniu nie sprawy konstruowania tożsamości, lecz jej zachowania (Bauman, 
1996, s. 23). Świat przestał być przyjazny pielgrzymom. Osoby i rzeczy straciły określoność i ciągłość. Nowe reguły „życia-gry konsumentów ponowoczesnych" wymagają bezustannej zmienności, krótkich gier, braku zaangażowania i przywiązania do miejsca, ruchliwości i fragmentacji, życia teraźniejszością kosztem przeszłości (Bauman, 1996, s. 24-26; Krajewska, 2015, s. 117-118). Wybór stał się wartością samą w sobie, a czynność wybierania stała się ważniejsza od efektów. Ostateczny „kres wybierania” przeraża nawet bardziej niż potrzeba codziennego wyboru, jak stwierdził Bauman (Jawłowska, 2001, s. 18). Niepotrzebne już są spójne i konsekwentne strategie życiowe. Potrzebne są takie, które pozwolą uciec od przywiązania i zakorzenienia. Wśród metafor tego typu tożsamości jednostkowych Bauman wymienia następców pielgrzyma: spacerowicza, włóczęgę, turystę i gracza (Bauman, 1995, s. 91-99).

Spacerowicz lub flâneur, będąc centralną figurą symboliczną współczesnego miasta, jest człowiekiem czasu wolnego, „figlarnym konsumentem” przyjemności. Jest to symbol człowieka nowoczesności, „skazanego na nieustanne przemieszczanie się w obrębie kolejnych tożsamości, któremu ramy wyznacza konsumpcyjny styl życia”. Flâneur jest również ofiarą społeczeństwa nadzorowanego, bowiem jest wystawiony na spojrzenia setek kamer (Brzozowska, 2009, s. 41). Spacer stał się sensem życia, zwłaszcza spacer w centrach handlowych, miejscem spotkań epizodycznych, nieprowadzących do żadnych poważnych następstw. Jednak spacerowicze nie są ostatecznie wolni, są bowiem niewidzialnie i nienatrętnie kierowani i uwodzeni (Bauman, 1995, s. 92-93). Poza kontrolą wydają się być włóczędzy, potencjalni lub rzeczywiści Inni, tak bliscy anarchii i chaosu. Kierunek ruchu włóczęgi był zawsze nieprzewidywalny, nie miał on wyznaczonego żadnego punktu przeznaczenia, wypychany przez nadzieje, rozwiane niedługo przed tym, a pociągany przez nadzieje jeszcze niewypróbowane. Jest obcy zawsze i wszędzie, gdzie pójdzie. Uwalnia go to od zatrzymania się gdziekolwiek i jakby odsuwa skończoną przyszłość (Brzozowska, 2009, s. 105-106). Jednak na etapie współczesnym zostaje coraz mniej miejsc, gdzie cokolwiek mogłoby włóczęgę powstrzymać, bo płynność ogarnia również niegdyś „osiadły” świat jego wędrówek (Bauman, 1995, s. 94-95). Włóczęgą ponowoczesności zostaje już przeciw własnym zamiarom, pod wpływem braku możliwości osiedlenia się, ostatecznie, braku wolności wyboru. 
Pewną wolnością wyboru trajektorii życiowej cieszy się alter ego włóczęgi, turysty (Bokszański, 2005, s. 256-257). Wędrówki turysty występują jako zajęcie najbardziej dziś pożądane, odbywają się w jakimś celu, przynajmniej w przekonaniu turysty. Takim celem są najczęściej nowe i rozmaitsze doświadczenia, ale bez żadnych zagrożeń, płynących od Innych, którzy zostali bezpiecznie włączeni do światowej oferty turystycznej. Świat turysty konstruowany jest według zasad estetyki, brutalne i przykre cechy świata włóczęgów są wymazywane z doświadczeń turysty. Turysta posiada dom, gdzie rozpakowuje rzeczy i może pokazać rzeczywistą twarz, lecz coraz bardziej dom odsuwa się gdzieś w projektowaną przyszłość, wywołując tęsknotę i marzenia o przynależności, które pozostają w planach i marzeniach na zawsze, bo znaczenie tożsamość ponowoczesna czerpie z płynności, ruchliwości i przestrzeni, w obawie przed nadmiernym „przywiązaniem do domu” jako dziwnego połączenia schronienia i więzienia (Bauman, 1995, s. 95-97).

Świat ponowoczesny jest światem gry, gdzie powodzenie i nieszczęście nie są niczym innym jak posunięciem każdego z graczy, mniej lub bardziej mądrym, praktycznym lub chytrym, wnikliwym lub błędnym. Jest to świat ryzyka, intuicji i ostrożności. Składa się na niego seria gier, każda uformowana według własnych zasad i znaczeń, zamknięta i samowystarczalna. Niespełniający warunków i sprzeciwiający się regułom po prostu przestaje być graczem w danej grze. Gra zawsze zaczyna się od zera i ma klarowny koniec, który trudno zakwestionować lub wyciągnąć konsekwencje. Gracz musi być pewien, że to tylko gra, nawet jeśli zaangażowane w nią zostają uczucia lub rodzina. Nie pozostawia ona bowiem miejsca dla litości, współczucie lub współpracę (Bauman, 1995, s. 98-99). Wszystkie cztery wymienione typy tożsamości mogą być sprzeczne wewnątrz lub między sobą, co wywołuje zdaniem Baumana cechy schizofreniczne osobowości ponowoczesnej, jej niepokój, zmienność i niezdecydowanie w strategiach życiowych.

Wymienione typy rzadko jednocześnie składają się na jeden styl życiowy, w warunkach globalizacji wolność wyboru trajektorii życiowych wyłania turystę i włóczęgę jako zasadnicze metafory panowania nad własną tożsamością. Tę „redystrybucję wolności” w dużej mierze wywołuje plastyczność i ruchliwość procesów identyfikacji. Z innej strony, globalizacja ma ogólny wpływ na stałość i trwałość tożsamości, zwłaszcza tej jej części, którą 
Bauman za Paulem Ricoeurem określa jako la mêmeté, czyli tożsamość względem siebie w czasie, wewnętrzna jedność i ciągłość w perspektywie kariery życiowej. Drugą stroną tożsamości jest zaś la ipseité, czyli różnice względem innych, Simmlowska odmienność, wyjątkowość osobowości. Chwiejność, zmienność, niestałość właściwa jest pierwszemu wymiarowi tożsamości, co w pełni odzwierciedla płynność i ruchliwość świata ponowoczesnego (Bauman, 2001, s. 11, Hałas, 2005, s. 33).

Bauman dodaje do tej koncepcji również hierarchię społeczną, którą zamieszcza między dwoma krańcami - krańcem turysty i jego wyboru autonomicznego, a krańcem włóczęgi, zdanego na „przydział tożsamości” (Bauman, 2001, s. 14). Poza autonomią ważne są również takie dychotomie jak: trwałość a elastyczność oraz autentyczność a nieautentyczność. We współczesnym świecie bowiem budulcem tożsamości stają się przedmioty rozmyślnie nietrwałe, często jednorazowe, bowiem - jak Bauman zacytował jednego z angielskich kolegów socjologów - to nie towarów dostarcza się ludziom, tylko ludzi - towarom (Bauman, 2006, s. 132). Z drugiej strony, Bauman krytykuje tzw. „spektakle szczerości” i „społeczeństwo wywiadów” (pojęcie Paula Atkinsona i Davida Silvermana), w których ludzie mniej lub bardziej znani odkrywają siebie, swoje życie, swoje autentyczne ja, subiektywną indywidualną prawdę, często rzekomo „tłumioną”, wykorzystując je jako narzędzie do utkania „W pełni indywidualnej tożsamości”. Bauman określa ten proces jako publicznie wytworzoną nieautentyczność, bowiem taka „możliwość «nabywania», wybierania i porzucania swojego «prawdziwego ja» oraz możliwość «bycia w ruchu» stały się oznakami wolności” (Bauman, 2006, s. 135; Orzyłowska, 2015, s. 117-118).

Wszystkich ludzi zatem łączy potrzeba uzyskiwania i przerabiania tożsamości, ale nie wszyscy zdolni są zaspokoić tę potrzebę zgodnie z prawdziwą lub domniemaną wolnością wyboru, ponieważ „w synoptycznym społeczeństwie nałogowych zakupowiczów i nałogowych widzów biedni nie mogą odwrócić wzroku, bo nie mają go gdzie odwrócić" (Bauman, 2006, s. 137, Ziętek, 2013, s. 211). Konsumowane towary stają się nowym punktem odniesienia, elementem symbolicznego konstruowania tożsamości związanej ze stylem życia, społecznym statusem, przynależnością grupową, dziś utraconej jako pewien stały konstrukt i punkt oparcia dla tożsamości. 


\section{REFLEKSYJNY PROJEKT TOŻSAMOŚCI ANTHONY'EGO GIDDENSA}

W koncepcji jednego z wiodących socjologów angielskich Anthony’ego Giddensa tożsamość zajmuje jedno z najważniejszych miejsc, przy tym jest ściśle połączona $\mathrm{z}$ analizą współczesnego społeczeństwa, a zwłaszcza procesów globalizacji, „globalnego zasięgu nowoczesnych instytucji, zmian, które przekładają się na życie jednostek i ich tożsamość” (Giddens, 2001, s. 3). Zmiany w obu obszarach, czyli na obu „krańcach”, można właściwie opisać i zrozumieć tylko z uwzględnieniem ich powiązań i wzajemnych zależności. W swojej koncepcji tożsamości Giddens stara się przezwyciężyć opozycję mechanizmów tożsamościowych i instytucjonalnych, lecz zauważa, że jednostka czynnie uczestniczy w procesach globalnych i jej tożsamość nie jest pasywnym wynikiem oddziaływań zewnętrznych (Giddens, 2001, s. 4).

Społeczeństwo późnej nowoczesności kształtuje się pod wpływem kilku czynników, wśród których można wymienić: tzw. opróżnianie czasu i przestrzeni poprzez rozpowszechnienie się zegara, uniwersalnego czasu oraz datowania, rozdzielenie czasu i przestrzeni, brak uwagi wobec specyfiki miejsca, dialektykę globalności i lokalności, czyli grę wzajemnych oddziaływań między uczestnictwem w kontekstach lokalnych a tendencjami globalnymi. Współdziałanie jaźni i społeczeństwa stało się możliwe dzięki wysokiemu poziomowi „rozsunięcia przestrzenno-czasowego” (Giddens, 2001, s. 46). Następnym bardzo ważnym czynnikiem jest wykorzenianie instytucji społecznych przez tzw. środki symboliczne, w tym pieniądz i inne środki wymiany, oraz systemy eksperckie, rozwijające prawomocną wiedzę ze wszystkich dziedzin nowoczesności, które razem się składają na systemy abstrakcyjne (Giddens, 2001, s. 24-27, 184-197).

Kluczowe znaczenie w schemacie Giddensa zajmują pojęcia zaufania i ryzyka. Zaufanie opiera się, z jednej strony, na przeszłych pozytywnych doświadczeniach i tendencjach, a z drugiej, na braku innego wyjścia dla współczesnego człowieka, skazanego na uwolnienie od czasowo-lokalnych odniesień, swojego rodzaju wirtualizację, nieobecność wiedzy w czasie i przestrzeni oraz niemożność ogarnięcia i zastosowania wiedzy specjalistycznej przez nie-eksperta. Zaufanie jest wplecione w rozwój osobowości, ale nie zawsze jest ono efektem świadomie podejmowanych decyzji (Giddens, 2001, s. 28). Niesie nie 
tylko bezpieczeństwo, lecz również ryzyko i zagrożenia o charakterze lokalnym i globalnym, wynikające $\mathrm{z}$ wielości nowych procesów, w które obfituje nowoczesność oraz niestabilności środowiska wiedzy. Zaufanie nie jest zawsze niezmienne, niekiedy łączy się z wygodą praktyczną związaną z pewnego rodzaju umową (Giddens, 2001, s. 31-32). Trzecim ważnym elementem jest tzw. refleksyjność, ze względu na którą instytucje nowoczesne są dynamiczne i podatne na rewizję pod wpływem nowej wiedzy. Zgodnie z definicją Giddensa, jest to „uregulowane wykorzystywanie wiedzy o warunkach życia społecznego jako konstytutywny element jego organizacji i przekształcania" (Giddens, 2001, s. 30).

Refleksyjność instytucjonalna jest również podstawą jaźni człowieka nowoczesności. Jego „Ja” staje się, wg Giddensa, „refleksyjnym projektem”, procesem, w ramach którego przy pomocy systemów abstrakcyjnych poprzez odkrywanie, mobilizację, konstruowanie odbywają się zmiany tożsamościowe (Giddens, 2001, s. 47). Świadomość refleksyjna oraz refleksyjna kontrola są niezbędne w działaniach ludzkich, warunkują nawet refleksyjność instytucjonalną, ogólnie bowiem bycie istotą ludzką oznacza ciągłą świadomość tego bycia. Niektórzy komentatorzy zarzucają koncepcji Giddensa nadmierną racjonalizację jednostki, która rozumiana jest wyłącznie w terminach poznania i refleksyjności, postępuje tylko „według zasad instrumentalnej racjonalności, strategicznej oceny przeszkód i możliwości oraz zarządzania ryzykiem w warunkach nieoznaczoności". Nieuwzględnione bowiem zostają normy i wartości, procesy socjalizacji i reprodukcji systemu (Bendle, 2002, s. 10-11).

Świadomość refleksyjna pomaga znaleźć odpowiedź na szereg pytań dotyczących fundamentów życia ludzkiego, m.in. „doświadczenia innych” i „ciągłości tożsamości” (Giddens, 2001, s. 50-78). W rozwoju świadomości jednostki, zwłaszcza na etapie początkowym, kluczową rolę odgrywa „odkrywanie innych" w sposób emocjonalno-poznawczy, później w procesie organizowania przewidywalnej interakcji jednostka uczestniczy w sposób czynny. Pod wpływem takiego czynnika nowoczesności jako „samozwrotność systemów społecznych” „inni” dostarczają coraz mniej wyznaczników zewnętrznych dla jednostki i jej indywidualnego projektu tożsamości, izolowanego względem zewnętrznych standardów i ocen (Giddens, 2001, s. 200-204). 
Aby znaleźć odpowiedź na pytanie dotyczące tożsamości, jednostka musi być zdolna do autorefleksji, posiadać świadomość refleksyjną. Samej jaźni jako „Czegoś danego w wyniku ciągłości działania jednostki”, jej trwałości w czasie nie wystarczy dla skonstruowania sprawnego projektu tożsamości, „rutynowo wytwarzanego i podtrzymywanego przez refleksyjnie działającą jednostkę" (Giddens, 2001, s. 74). Chociaż tożsamość, zdaniem Giddensa, nie jest zespołem rys charakterystycznych jednostki, lecz refleksyjną interpretacją przez jednostkę ciągłości w czasie i przestrzeni, czyli pojmowaniem jej w terminach biograficznych, poprzez tworzenie unikatowej i ciągłej „narracji”, opisanie przebiegu własnego życia, „refleksyjną kontrolę rzeczywistości” (Giddens, 2001, s. 76-77).

Giddens odrzuca takie rozumienie tożsamości, w którym nacisk kładzie się na zachowanie jednostki lub sposób, w jaki jest odbierana przez innych, bowiem z charakterystyk osobowościowych i strukturalnych oraz postrzegania jednostki przez innych nie da się wprost wyprowadzić jej tożsamości. Zależy ona od kruchej i stabilnej jednocześnie biografii, przywoływanej refleksyjnie, opartej na ciągłej i wszechogarniającej refleksyjności „ja”. Jednostka jest sama odpowiedzialna za refleksyjny projekt, który realizuje w procesie konstruowania własnej tożsamości, nie tylko lepszego poznawania „ja” w sensie psychologicznym, lecz samorozumienia w celu wytworzenia spójnego oraz satysfakcjonującego poczucia tożsamości. Tożsamość wytwarza się w przebiegu wielu różnych faz życia, czego jednostka jest świadoma jako spójnej „trajektorii tożsamości”, wyrażającej się w ciągłej narracji, opartej na własnej przeszłości jednostki, którą ta przystosowuje do perspektywy refleksyjnie zorganizowanej przyszłości, „uporządkowanej przez procesy czynnej kontroli i czynnej interakcji” (Giddens, 2001, s. 104-107). Jak podsumował Anthony Elliott, głównym czynnikiem w wytwarzaniu zarówno tożsamości, jak i społeczeństwa u Giddensa są rutynowe czynności, specyficzne nawykowe praktyki, bowiem jest to „integralny aspekt zarówno ciągłości osobowości podmiotu w toku jego czynności codziennych, jak i instytucji społecznych, którym kształt nadaje ich odtwarzanie" (Elliott, 2011, s. 170).

Oprócz narracji własnego rozwoju, trajektorii życia „ja” w konstruowaniu tożsamości zintegrowanej, „osiągnięciu »ja « autentycznego” duże znaczenie ma wytworzenie przez jednostkę własnego systemu przekonań, „wewnętrznych punktów odniesienia”, które są podstawą lojalności jednostki w stosunku 
do siebie i spójności tożsamości jaźni. Czynniki zewnętrzne przy tym postrzegane są jako przyjazne lub przeszkadzające w rozwoju, również jako źródła wątpliwości. Efektem wpływów nowoczesności i jej systemów abstrakcyjnych stało się więc poczucie samotności, opuszczenia i braku bezpieczeństwa w świecie, gdzie znikły tradycyjne układy i wspólnotowość. W zamian przyszli eksperci i terapeuci, również jako wyraz refleksyjności tożsamości i instytucji nowoczesnych, co bardzo często prowadzi do poczucia utraty kompetencji przez jednostkę, nawet jej alienacji w wyborze i dalszym strategicznym planowaniu stylu życia, przekształcającego się w towar, jeden z szerokiego asortymentu standaryzowanych wzorów konsumpcji.

Świat późnej nowoczesności dostarczył jednostce wiele opcji do konstruowania refleksyjnego projektu tożsamości jaźni, jednak umieścił prawie wszystkie w ramach dostępnego asortymentu rynkowego, który kształtuje się w zakresie szerszych procesów globalnych, wykraczających poza ustalenia lokalne. Jednostka zyskała samodzielność, lecz za cenę uświadamiania indywidualnej odpowiedzialności za wszystkie podejmowane decyzje i wybory na każdym etapie swych działań.

\section{Podsumowanie}

W artykule zostały przeanalizowane wybrane socjologiczne, społeczno-psychologiczne oraz filozoficzne koncepcje tożsamości jednostki ludzkiej z ostatniego ćwierćwiecza XX w. oraz początku XXI w., które powstały w kontekście anglosaskiego i francuskiego dyskursu naukowego. Przeanalizowany dorobek McCalla i Simmonsa, Touraine’a, Bourdieu, Baumana i Giddensa został przedstawiony jako część szerszego pola badań nad podmiotem czy agentem społecznym w ścisłym związku z takimi pojęciami jak rola społeczna i system społeczny, ruch społeczny i zmiany społeczne, konsumpcja, indywidualizm oraz kapitał kulturowy. W trakcie analizy wyłonił się obraz jednostki ludzkiej, która świadomie kształtuje swoją tożsamość, ale zaczynając nie od carta blanca, a od określonego kontekstu kulturowego i społecznego. Zmienność tego kontekstu wymusza na jednostce ciągłą troskę o jednoczesną aktualizację tożsamości zgodnie z dostępnym wachlarzem wyboru konsumpcyjnego oraz potrzebę potwierdzania zakorzenienia $\mathrm{w}$ aktualnych powszechnie akceptowalnych praktykach. 


\section{Literatura}

Bauman, Z. (1996). From Pilgrim to Tourist - or a Short History of Identity. W: S. Hall, P. du Gay, (red.) Questions of Cultural Identity, London: Sage, s. 18-19. ISBN 9780803978836.

Bauman, Z. (1995). Life in fragments: Essays in Postmodern Morality, Cambridge, Oxford. MA: Wiley-Blackwell 1995. ISBN 9780631192671.

Bauman, Z. (2006). Płynna nowoczesność, Kraków: Wydawnictwo literackie. ISBN 8308038476.

Bauman, Z. (2001). Tożsamość - jaka była, jest i po co?. W: A. Jawłowska (red.), Wokół problemów tożsamości, Warszawa: Wydawnictwo LTW, s. 8-25. ISBN: 83887360433.

Bendle, M.F. (2002). The Crisis of "Identity” in High Modernity, „British Journal of Sociology" Vol. 53. No. 1, s. 1-18. ISSN 0007-1315.

Blumstein, P.W. (1975). Identity Bargaining and Self-Conception, „Social Forces” Vol. 53, No. 3 (March), s. 476-485. ISSN 0037-7732.

Bokszański, Z. (1999). Tożsamość aktora społecznego a zmiana społeczna. W: J. Kurczewska (red.), Zmiana społeczna. Teorie i doświadczenia polskie, Warszawa: Instytut Filozofii i Socjologii PAN, s. 55-73. ISBN 838763235X

Bokszański, Z. (1989). Tożsamość, interakcja, grupa, Łódź: Wydawnictwo Uniwersytetu Łódzkiego. ISBN 8370163556.

Bokszański Z. (2005). Tożsamości zbiorowe, Warszawa: Wydawnictwo Naukowe PWN. ISBN 8301144092.

Bourdieu, P. (1994). Raisons pratiques. Sur la théorie de l'action, Paris: Seuil. ISBN 9782020231053

Bourdieu, P. (2010). Distinction. A Social Critique of the Judgement of Taste, New York, London: Routledge. ISBN 9780415567886.

Bourdieu, P., Wacquant, L.J.D. (2001). Zaproszenie do socjologii refleksyjnej, Warszawa: Oficyna Naukowa. ISBN 8388164333.

Brzozowska, B. (2009). Spadkobiercy flâneura. Spacer jako twórczość kulturowa - wspótczesne interpretacje, Łódź: Wydawnictwo Uniwersytetu Łódzkiego. ISBN 9788375253221.

Burke, P.J., Stets, J.E. (2009). Identity Theory, New York: Oxford University Press. ISBN 9780195388275.

Burke, P.J., Stets, J.E. (2000). Identity Theory and Social Identity Theory, „Social Psychology Quarterly", Vol. 63, No. 3, (Sept., 2000), s. 224-237. ISSN 0190-2725. 
Elliott, A. (2011). Wspótczesna teoria społeczna, Warszawa: PWN. ISBN 9788301166397.

Giddens, A. (2001). Nowoczesność i tożsamość. „Ja” i społeczeństwo w epoce późnej nowoczesności, Warszawa: PWN. ISBN 9788301162252.

Giddens, A. (2004). Socjologia, Warszawa: PWN. ISBN 8301142251.

Hałas, E. (2005). Jaźń jako interakcja symboliczna a konstrukcjonistyczne koncepcje człowieka późnej nowoczesności. W: E. Hałas i K. Konecki (red.), Konstruowanie jaźni i społeczeństwa. Europejskie warianty interakcjonizmu symbolicznego, Warszawa: Wydawnictwo Naukowe Scholar, s. 23-39. ISBN 8373831444.

Jacyno, M. (2007). Kultura indywidualizmu, Warszawa: PWN. ISBN 9788301150723. Jawłowska, A. (red.). (2001). Wokót problemów tożsamości, Warszawa: Wydawnictwo LTW, s. 8-25. ISBN 83887360433.

Jenkins, R. (2005). Social identity, London: Routledge. ISBN 1134326939.

Kaufmann, J.-C. (2004). Ego. Socjologia jednostki, Warszawa: Oficyna Naukowa. ISBN 83-88164-77-5.

Krajewska, A. (2015). Konsumpcjonizm jako zagrożenie dla dzieci i młodzieży. Wyzwania dla edukacji, „Journal of Modern Science” 3/26, s. 115-127. ISSN 1734-2031.

Magala, S.J. (2002). Elective Identities (Culture, Identization and Integration) (22.10.2002). ERIM Report Series Reference No. ERS-2002-92-ORG, https://ssrn. com/abstract=371034 (dostęp: 25.11 .2017$)$.

Matuchniak-Krasuska, A. (2010). Zarys socjologii sztuki Pierre’a Bourdieu, Warszawa: Oficyna Naukowa.

McCall, G.J., Simmons, J.L. (1978). Identities and Interactions, New York: The Free Press. ISBN 9780029206201.

McCall, G.J. (2011). The Me and the Not-Me. Positive and Negative Poles of Identity. W: Burke, P.J., Owens, T.J., Serpe, R., Thoits, P.A. (red.), Advances in Identity Theory and Research, New York: Springer Science \& Business Media. ISBN 1441991883.

Misztal, B. (2000). Teoria socjologiczna a praktyka społeczna, Kraków: Universitas. ISBN 8370527493.

Novikova, K. (2013). Społeczne teorie tożsamości: przegląd wybranych koncepcji, „Journal of Modern Science" 2/17, s. 377-395. ISSN 1734-2031.

Novikova, K. (2016). Zarządzanie sukcesem w rozwoju osobistym, „Journal of Modern Science" 4/31, s. 157-176. ISSN 1734-2031.

Orzyłowska, A. (2015). Konsumpcjonizm jako zagrożenie dla bezpieczeństwa indywidualnego człowieka, „Journal of Modern Science” 2/25, s. 111-125. ISSN 1734-2031. 
Sitek, M. (2015). Tożsamość narodowa (europejska) a obywatelstwo Unii Europejskiej, "Journal of Modern Science” 4/27, s. 111-126. ISSN 1734-2031.

Stryker, S. (1981). Symbolic Interactionism: Themes and Variations. W: M. Rosenberg and R.H. Turner (red.), Social Psychology: Sociological Perspectives, New York: Basic Books, s. 3-29. ISBN 0465079040

Tourain, A. (1992). Critique de la modernité, Paris: Fayard. ISBN 9782213030050.

Tourain, A. (2011). Mysleć inaczej, Warszawa: Państwowy Instytut Wydawniczy. ISBN 9788306032673.

Tourain, A. (1988). Return of the Actor. Social Theory in Post-Industrial Society, Minnesota: University of Minnesota. ISBN 9780816615940.

Turner, J.H. (2004). Struktura teorii socjologicznej, Warszawa: Wydawnictwo Naukowe PWN. ISBN 830114072001.

Ziętek, A. (2013). Jean Baudrillard wobec wspótczesności. Polityka, media, społeczeństwo, Kraków: Universitas. ISBN 9788324223558.

\section{Endnotes}

${ }^{1}$ Tutaj i dalej tłumaczenie własne Autorki. 
